\title{
MANAJEMEN PRANIKAH DALAM PENINGKATAN PEMAHAMAN KEAGAMAAN CALON PENGANTIN DI KUA KECAMATAN PAHANDUT KOTA PALANGKA RAYA
}

\author{
Syahmidi, S.Th.I., M.Pd.I
}

\section{IAIN PALANGKA RAYA}

\begin{abstract}
Abstrak
Tujuan penelitian ini adalah untuk mengetahui pola pembinaan pranikah, seberapa besar peningkatan pemahaman keagamaan bagi calon pengantin serta faktor pendukung dan penghambat pembinaan pranikah. Jenis penelitian ini bersifat kualitatif deskriptif. Tempat penelitian adalah KUA Kecamatan Pahandut kota Palangka Raya, dengan subjek penelitian adalah Kepala KUA, Penghulu, Ketatausahaan dan sebanyak 14 pasangan calon pengantin. Teknik pengumpulan data menggunakan angket, wawancara dan observasi. Sedangkan analisis data menggunakan reduksi data, display dan verifikasi data atau kesimpulan. Hasil dari penelitian ini adalah I) Pola pembinaan yang dilakukan KUA Kecamatan Pahandut meliputi model pembinaan, pembimbing pembinaan, materi pembinaan, metode pembinaan dan waktu pembinaan. Secara kesimpulan tingkat pola pembinaan termasuk kategori baik (79,29\%). 2) Tingkat pemahaman keagamaan meliputi pemahaman akad nikah, pemahaman kesehatan reproduksi, pemahaman ibadah dan pemahaman psikologi keluarga. Secara kesimpulan tingkat pemahaman keagamaan termasuk kategori 'Tinggi' (83,04\%). 3) Factor pendukung pembinaan meliputi antusiasme peserta, pembimbing yang kompeten dan metode penyampaian yang sangat sederhana. Sedangkan faktor penghambat meliputi sarana dan prasana yang belum memadai, materi bimbingan yang kurang lengkap dan waktu bimbingan yang sangat singkat.
\end{abstract}

\section{Kata Kunci: manajemen pembinaan calon pengantin, pemahaman keagamaan}

\section{Latar Belakang}

Pernikahan adalah ikatan yang mulia dan diberkahi. Allah SWT mensyari'atkan pernikahan untuk kemaslahatan dan kemanfaatan hambahambanya, agar dengan mereka dapat mencapai maksud-maksud yang baik dan tujuan-tujuan yang mulia. Akad nikah adalah perjanjian suci antara seorang pria dan seorang wanita membentuk keluarga bahagia dan kekal. Dalam UU Perkawinan Nomor I tahun 1974 Pasal (I) disebutkan bahwa perkawinan adalah ikatan lahir batin antara seorang pria dan seorang wanita sebagai suami istri dengan tujuan membentuk keluarga bahagia yang kekal berdasarkan Ketuhanan Yang Maha Esa. Al-Qur'an dan Hadits Nabi memberikan penjelasan bahwa Allah SWT menganjurkan hamba-hambanya untuk menikah bagi mereka yang mampu baik lahir maupun batin karena perkawinan merupakan hal yang penting bagi kehidupan manusia, maka perkawinan yang dilakukan seseorang itu haruslah perkawinan yang sah. Sebagaimana tercantum dalam Pasal 2 UU No. I tahun 1974 "Perkawinan adalah sah apabila dilakukan menurut masing-masing agama". Karena menikah dalam UU Perkawinan harus didasarkan pada ajaran agama, maka hal ini selaras dengan prinsip-prinsip Islam bahwa pernikahan adalah bagian dari ajaran Islam. Maka kehidupan seorang muslim tidak sekedar urusan sholat, puasa, haji saja yang menjadi bagian dari Islam, namun juga urusan pernikahan dan keluarga.

Pembinaan bagi calon pengantin merupakan suatu keabsahan pernikahan dari kepedulian pemerintah, hal ini sesuai dengan Peraturan Direktur Jenderal Bimbingan Masyarakat Islam Departemen Agama Nomor: Dj.II/49I Tahun 2009 tentang kursus calon pengantin. Salah satu isi butir peraturan tersebut pasal I ayat 2 adalah "kursus calon pengantin yang selanjutnya disebut dengan suscatin adalah pemberian bekal pengetahuan, pemahaman dan ketrampilan dalam waktu singkat kepada catin tentang kehidupan rumah tangga/keluarga. Dalam Peraturan Direktur Dirjen Bimbingan Masyarakat Islam Nomor DJ..II/542 Tahun 2013 Tentang Penyelenggaraan Kursus Pra Nikah Bab III Pasal 3 ayat (2) disebutkan bahwa Kementerian Agama dapat menyelenggarakan kursus pra nikah yang pelaksanaannya bekerja sama dengan Badan Penasihatan, Pembinaan, dan Pelestarian Perkawinan (BP4) atau organisasi keagamaan Islam lainnya. Berdasarkan latar belakang masalah 
di atas, maka rumusan masalah yang dijadikan pokok penelitian ini adalah:

I. Bagaimana manajemen pembinaan pranikah di Kantor Urusan Agama Kecamatan Pahandut?

2. Bagaimana faktor pendukung dan penghambat pembinaan pranikah di KUA Kecamatan Pahandut?

\section{Hasil Penelitian}

I. Manajemen Pembinaan Pranikah

Secara umum ada tiga tahap pada pembinaan yaitu tahap perencanaan pembinaan, tahap pelaksanaan pembinaan dan tahap evaluasi pembinaan.

a. Model Pembinaan

Model pembinaan adalah gambaran tentang suatu usaha atau kegiatan yang dilakukan secara berdaya guna memperoleh hasil yang baik. Pembinaan memberikan arah penting dalam memberikan informasi kepada seseorang dalam hal ini adalah calon pengantin, mengenai arah tujuan dan jauh catin mengetahui tentang pernikahan dan juga agama".

Berdasarkan penjelasan di atas dapat diambil kesimpulan bahwa model atau pola pembinaan di KUA Kecamatan Pahandut adalah klasikal dan individual. Berdasarkan angket, dapat dijelaskan sebanyak $50,00 \%$ calon pengantin sangat setuju dengan model pembinaan yang dilakukan oleh KUA, sebanyak 35,71\% setuju dan sebanyak $14,29 \%$ kurang setuju. Alasan mengenai ada calon pengantin yang kurang setuju dapat dicermati dari hasil wawancara berikut:

Sebenarnya bukannya saya kurang setuju. Saya lebih suka kalau model pembinaan terprogram sehingga kami calon pengantin dalam mengikuti pembinaan ini benar-benar paham dan mengerti tentang tugas sebagai suami maupun istri setelah menikah.

\section{b. Pihak Yang Terlibat}

Pihak yang ada dalam pembinaan tidak hanya calon pengantin dan pihak KUA saja akan tetapi ada juga pihak lain yang ikut dalam pembinaan tersebut, peneliti melakukan wawancara kepada penghulu, beliau juga menuturkan bahwa pihak yang terlibat dalam pembinaan adalah sebagai berikut:

"Pihak yang terlibat dalam pembinaan ini calon pengantin, tokoh agama, pemerintah desa dan juga puskesmas karena apa puskesamas juga terlibat karena untuk mengetahui kondisi pandangan hidupnya. Model pembinaan juga dilakukan untuk secara berkesinambungan dan dilakukan secara sadar oleh suatu lembaga dalam rangka menumbuh-kembangkan aspek kognitif, afektif maupun psikomotorik disertai spiritual yang kuat. Mengenai model pembinaan di KUA Kecamatn Pahandut dapat dicermati dari hasil wawancara dengan bapak penghulu berikut ini.

Kalau model pihak KUA melakukan pembinaan pada saat pemeriksaan catin dan pada saat akan berlangsungya pernikahan, serta pihak KUA juga memanggil catin untuk datang ke KUA, kita kumpulkan dalam sebuah ruangan, kemudian kita lakukan pembinaan secara bersama-sama. Selain itu juga adanya proses tanya jawab yang dilakukan oleh pihak pegawai KUA terhadap catin itu sendiri serta seberapa

kesehatan dari pihak calon pengantin karena sangat penting untuk mengatahui kondisi kesehatan, bukanya Rasulullah juga menegaskan bahwa kawinilah wanita yang dapat memberika keturunan yang banyak bagi kamu".

Dengan banyaknya pemateri dan berasal dari berbagai kalangan diharapkan penyampaian pembinaan semakin bervariatif dan sesuai dengan kemampuan dan pengetahuan masing-masing. $\mathrm{Hal}$ ini diperkuat dengan hasil wawancara dengan calon pengantin.

Tadi aku lihat ada tokoh agama, kesehatan dan KUA sendiri. Jadi secara penguasaan materi sepertinya lebih bagus.

Berdasarkan angket, dapat dijelaskan sebanyak $57,14 \%$ calon pengantin sangat setuju dengan pembimbing pembinaan yang dilakukan oleh KUA dan sebanyak 42,86\% setuju.

c. Materi Pembinaan

Dalam melaksanakan pembinaan tentu juga dari pihak KUA memiliki materi tersendiri yang nantinya akan diberikan kepada calon pengantin. Hal ini diperkuat dengan hasil wawancara:

Secara standar sesungguhnya materi sudah ada aturan atau materi yang akan diberikan, namun KUA biasanya memiliki materi tersendiri yang akan diberikan tentang misalnya seperti ilmu-ilmu fiqih, tentang membina keluarga dan bagaimana nikah yang sebenarya, serta nikah 
sebagai menjalin hubungan rumah tangga yang harmonis.

Sedangkan ada tanggapan dari calon pengantin ternyata bervariatif, salah satunya adalah:

Materi pembinaan sangat banyak sedangkan waktunya hanya sebentar. sebanyak $28,57 \%$ setuju dan

14,29\% kurang setuju.

d. Metode Pembinaan

Secara metode pembinaan tidak ada aturan yang baku dan secara teoritis tidak ditemukan refensi khusus mengenai metode pembinaan pranikah. Namun dalam pembinaan pranikah cenderung menggunakan beberapa metode baik digunakan secara kelompok maupun individu. Di antara metode tersebut adalah:

Biasanya para peserta calon pengantin dipersilahkan masuk dalam sebuah ruangan terus dilakukan pembinaan. Metode yang sering digunakan ya...seperti ceramah, tanya jawab atau diskusi. Intinya bagaimana pembinaan tersebut dapat dipahami oleh peserta dengan mudah. Itu saja.

Berdasarkan penjelasan dari Kepala KUA Kecamatan Pahandut di atas, dapat dijelaskan bahwa metode yang sering digunakan adalah: metode diskusi, Tanya jawab dan metode ceramah. Berdasarkan angket, dapat dijelaskan sebanyak 35,7l\% sangat setuju dengan metode yang diberikan, sebanyak $42,86 \%$ setuju dan $21,43 \%$ kurang setuju.

e. Waktu Pembinaan

Waktu pembinaan menjadi masalah yang sangat krusial, karena mayoritas calon pengantin adalah bekerja, sehingga perlu waktu yang tepat agar calon pengantin bisa hadir sesuai dengan undangan pembinaan. Waktu pembinaan dilaksanakan setiap hari Rabu dari pukul 13.00-16.00 wib, sekitar 3 jam dan hanya dilakukan sekali. Biasanya dilakukan I bulan sebelum atau paling dekat I minggu sebelum pernikahan.

"Waktu pelaksanaan pembinaan kami lakukan pada saat akan berlangsungya ijab qabul karena kalau kita memanggil satu persatu calon penganti untuk melakukan dengan mengetahui latar belakang calon pengantin, maka di dalam melakukan pembinaan lebih tepat sesuai dengan kebutuhan yang
Sehingga kesan dipaksakan dan sekedar formalitas. Semuanya memang peenting namun seharusnya jangan begini.

Berdasarkan angket, dapat dijelaskan sebanyak 57, I4\% sangat setuju dengan materi yang diberikan, pembinaan dari pihak calon pengantin sering tidak bisanya karena terbentur jarak dan juga waktu, yang mana kebanyakan calon pengantin pekerja buruh di pabrik sehingga waktu untuk liburpun juga tidak ada maka dari itu pihak KUA juga melakukan inisiatif terebut, iya memang ada satu atau dua calon pengantin yang kita panggil ke KUA untuk melakukan pembinaan tersebut".

Berdasarkan angket dapat

diperhatikan bahwa sebanyak I4,29\% sangat setuju, $28,57 \%$ setuju, $35,71 \%$ kurang setuju dan 2I,43\% tidak setuju. Alasan mengenai ada yang tidak setuju dengan waktu adalah sebagai berikut:

Menurut saya waktu yang diberikan sangat kurang, dengan materi yang banyak waktu pembinaan hanya sekitar 3 jam dan itu saja hanya sekali. Padahal pernikahan merupakan sesuatu yang penting. Harapannya dengan mengikuti pembinaan kami menjadi paham dan memliki persiapan yang matang secara lahir dan batin setelah kami menikah nanti. Seharusnya waktu yang diberikan lebih lama dan materi bisa disampaikan secara komperhensif.

Untuk efektivitas waktu

pembinaan memang perlu mendapatkan perhatian dari pihak KUA. Hal ini diperkuat dengan hasil wawancara dengan calon pengantin.

Dengan materi sebanyak itu dan waktu pembinaan hanya sekitar 3 jam sangat tidak efektif. Apalagi masa pertemuan hanya sekali. Seharus tidak hanya sekali namun 23 kali pertemuan.

Sedangkan untuk materi, pihak

KUA perlu memperhatikan latar belakang calon pengantin. Karena setiap calon pengantin memiliki latar belakang pendidikan, social dan budaya. Hal ini akan membantu pembimbing karena

diharapkan calon pengantin. $\mathrm{Hal}$ ini diperkuat dengan hasil wawancara.

Menurut saya materi sudah bagus, namun terlalu banyak. Sehingga 
dalam waktu yang singkat namun diberi materi sebanyak itu akhirnya ya....gimana? Menurut saya, diharapkan pihak KUA mengetahui latar belakang calon pengantin, sehingga sisi kelemahan dari calon pengantin itulah yang seharusnya dibina oleh KUA. Misalnya calon pengantin yang lemah dalam sisi pengetahuan keagamaan, maka dalam pembinaan lebih diperbanyak porsi pengetahuan tentang agama dan seterusnya.

Berdasarkan penjelasan di atas dapat disimpulkan bahwa pola pembinaan pranikah termasuk kategori Baik (77,86\%). $\mathrm{Hal}$ ini dapat diperhatikan pada tabel berikut:

\begin{tabular}{|c|l|c|c|c|c|}
\hline No & Kategori & $\begin{array}{c}\text { Jumla } \\
\mathrm{h} \\
\text { Skor }\end{array}$ & $\begin{array}{c}\text { Persenta } \\
\text { se (\%) }\end{array}$ & $\begin{array}{c}\text { Rata } \\
- \\
\text { rata }\end{array}$ & $\begin{array}{c}\text { Katego } \\
\text { ri }\end{array}$ \\
\hline I & Model & 47 & 83.93 & & \\
\cline { 1 - 4 } 2 & $\begin{array}{l}\text { Pembimbi } \\
\text { ng }\end{array}$ & 50 & 89.29 & \multirow{2}{*}{79.2} & \multirow{2}{*}{ Baik } \\
\cline { 1 - 4 } 3 & Materi & 46 & 82.14 & \multirow{2}{*}{9} & \\
\hline 4 & Metode & 48 & 85.71 & & \\
\hline 5 & Waktu & 31 & 55.36 & & \\
\hline
\end{tabular}

2. Peningkatan Pemahaman Keagamaan Calon Pengantin

Efektivitas dari pola pembinaan yang dilakukan oleh KUA Kecamatan Pahandut telah memberikan dampak positif terhadap para calon pengantin. Berdasarkan hasil ceklis dan wawancara diperoleh data sebagai berikut:

a. Tata cara akad nikah

Perlaksaan akad nikah merupakan sesuatu yang sakral dalam agama Islam. Akad nikah terdiri dari dua kata yaitu akad yang berarti janji, kotrak atau perjanjian serta nikah yang berarti ikatan. Akad Akad nikah adalah perjanjian yang berlangsung antara dua pihak yang melangsungkan perkawinan dalam bentuk ijab dan qabul. Sedangkan definisi akad nikah dalam Kompilasi

Dalam Islam, kedudukan

shalat sangat penting. Karena shalat merupakan rukun Islam kedua setelah syahadat. Shalat adalah tiang agama, maka jika seseorang tidak shalat maka orang tersebut telah merobohkan agama. Berdasarkan angket maka diperoleh sebanyak $50,00 \%$ sangat setuju, sebanyak $42,86 \%$ setuju dan 7,14\% kurang setuju. Hal ini sesuai pengakuan seorang calon pengantin.

Setelah mengikuti pembinaan saya menjadi lebih semangat beribadah khususnya shalat.
Hukum Islam yang termuat dalam Bab I pasal I (c) yang berbunyi: Akad nikah adalah rangkaian ijab yang diucapkan oleh wali dan qabul yang diucapkan oleh mempelai pria atau wakilnya disaksikan oleh dua orang saksi. Jadi, akad nikah adalah perjanjian dalam suatu ikatan perkawinan yang dilakukan oleh mempelai pria atau yang mewakilinya, dengan wali dari pihak wanita calon pengantin atau yang mewakilinya, dengan menggunakan sighat ijab dan qabul. Berdasarkan angket, sebanyak $64,29 \%$ peserta calon pengantin sangat setuju bahwa mereka tingkat pemahaman meningkat dan sebanyak 35,7l\% setuju. $\mathrm{Hal}$ ini didukung dengan hasil wawancara mereka:

Awalnya kami tidak mengetahui tentang tata cara akad nikah. Setelah mengikuti pembinaan kami menjadi paham. Bahwa menikah tidak hanya sekedar janji kepada pasangan kita melainkan dunia akhirat.

Sedangkan wawancara dengan penghulu tentang materi pembinaan tata cara nikah yang meliputi:

Materi tentang tata cara akad ya standar meliputi pemberitahuan kehendak nikah, ljab Kabul, perjanjian perkawinan, kutipan akta nikah, contoh khutbah nikah, penasehatan perkawinan.

b. Peningkatan dalam Ibadah

Seluruh kehidupan manusia adalah medan amal dan persendian bekal bagi umat Islam sebelum kembali menghadap Allah swt. Dalam penelitian ini, peneliti fokus terhadap ibadah shalat, puasa dan membaca al-Qur'an.

I) Meningkatnya ibadah Shalat Wajib

Yang dulu masih bolongbolong sekarang lebih tertib. $\mathrm{Hal}$ ini karena semakin tahu tentang tanggung jawab ke depan sebagai suami yang cukup besar.

2) Kebiasaan Membaca al-Qur'an

Al-Qur'an artinya bacaan. Al-Qur'an juga diartikan sebagai bacaan yang maha sempurna dan mulia. Kemulian dan kesempurnaan al-Qur'an tidak hanya dirasakan oleh ahli tafsir, namun masyarakat awampun bisa merasakannya. Banyak sekali penelitian modern yang 
mengatakan bahwa al-Qur'an mampu memberikan kercerdasan intelektual dan ketenangan secara emosional. Orang yang membaca setiap hari selain mendapatkan pahala yang besar juga akan memberikan efek positif terhadap tubuh dan kepribadiannya.

Aku sangat merindukan bisa ngaji bareng dengan istri. Karena calon istriku lebih lancer membaca al-Qur'an, maka mulai sekarang aku belajar semakin sering membaca. Biar sama-sama bisa ngaji bareng ketika sudah menikah nanti.

c. Psikologi Pernikahan

I) Semakin Banyak Berdoa

$$
\text { Doa }
$$

adalah

kecenderungan hati kepada Allah atau menghadirkan Allah ke dalam sanubari seseorang, dalam arti mengingat-ingat Allah di dalam sanubari, menyebut dan memanggil-Nya dengan harapan dia akan selalu menyertai kita. Berdasarkan tabel di atas dapat dijelaskan bahwa sebanyak 57, I4\% sangat setuju dan $42,86 \%$ setuju. $\mathrm{Hal}$ ini diperkuat dengan wawancara calon pengantin sebagai berikut:

$7,14 \%$ tidak setuju. $\mathrm{Hal}$ ini diperkuat dengan hasil wawancara.

$$
\begin{aligned}
& \text { "Ya setelah menikah } \\
& \text { harapannya bisa memiliki } \\
& \text { rumah sendiri, kalau belum } \\
& \text { bisa ya cari kos belajar } \\
& \text { mandiri. }
\end{aligned}
$$

3) Lebih Giat dalam Bekerja

\begin{tabular}{ll}
\multicolumn{2}{c}{ Orang-orang hebat } \\
biasanya dikendalikan oleh
\end{tabular}
keyakinan (belief) positif yang kuat dan sebaliknya orang yang biasabiasa saja dikendalikan oleh sesuatu yang biasa dan lemah. Manusia sebaiknya mengembangkan kekuatan yang dimiliki dan jangan putus asa terhadap hasil yang belum sesuai dengan harapan. Karena keputusasaan hanya akan membaut semakin kecewa dan semakin jauh dari keberhasilan. Berdasarkan angket, dapat digambarkan sebanyak $64,29 \%$ sangat setuju dan $35,71 \%$ setuju. Hal ini diperkuat
Ya sekarang setelah pembinaan kemarin, makin deg-degan. Untuk itu makin banyak berdoa supaya dilancarkan semuanya. Khususnya semoga nanti menjadi keluarga yang sakinah mawadhah warahmah.

2) Semakin Semangat Berusaha Mewujudkan Cita-cita

Ikhtiar adalah berusaha dengan mengerahkan segala kemampuan yang ada untuk meraih suatu harapan dan keinginan yang dicita-citakan, atau dengan kata lain ikhtiar juga juga dapat diartikan sebagai usaha sungguh-sungguh yang dilakukan untuk mendapatkan kebahagiaan hidup, baik di dunia maupun di akhirat. Segala usaha yang dikerahkan manusia harus didasari keyakinan kepada Allah. Sehingga jangan sampai manusia memperlemah keyakinan yang akhirnya memunculkan rasa sombong dihadapan Allah dan sesama manusia. Berdasarkan angket dapat dijelaskan bahwa sebanyak $31,71 \%$ calon pengantin sangat setuju, sebanyak 50,00\% setuju, $7,14 \%$ kurang setuju dan sebanyak

dengan hasil wawancara sebagai berikut:

Kalau dulu ketika kerja, milihmilih kalau enggak gajinya tinggi keluar, tapi sekarang lebih cenderung memilih mensyukuri yang telah ada yang penting halal. Dalam bekerja lebih semangat karena ada orientasi untuk pernikahan ya tetap memerlukan biaya yang tidak sedikit.

4) Semuanya semakin Dipasrahkan Kepada Allah

Tawakal adalah merupakan salah satu ajaran pokok dalam Islam. Tawakal adalah menyerahkan kepada kehendak dan ketentuan Allah, yang dilandasi kesadaran akan kelemahan diri sendiri, dan berdasarkan kepercayaan yang kuat kepada qudrah dan kebijaksanaan Allah. Berdasarkan tabel di atas dapat digambarkan 
bahwa sebanyak $71,43 \%$ sangat setuju dan $28,57 \%$ setuju manusia perlu tawadhu. Hal ini diperkuat dengan hasil wawancara sebagai berikut:

\begin{abstract}
Kalau masih berstatus pacaranya, semua dibuat serba ini itu. Namun setelah pembinaan materi psikologi pernikahan. Semuanya lebih cenderung dipasrahkan kepada yang Diatas. Berusaha dan berdoa tetap dilakukan. Tapi apapun hasilnya itu sudah urusan Yang Diatas.
\end{abstract}

5) Bersyukur Karena Telah Diberi Kelancaran

Syukur merupakan salah satu dari kajian psikologi positif tersebut, yang berarti mengucapkan terima kasih atas anugerah. Syukur memiliki hubungan positif dengan berbagai emosi positif seperti kepuasan hidup, kebahagiaan, mudah

3. Faktor Pendukung dan Penghambat Pembinaan Pra Nikah

Pelaksanaan bimbingan pranikah bagi calon pengantin di KUA Kecamatan Pahandut sudah cukup efektif. Begitu pula dengan program bimbingan pranikah di Kantor Urusan Agama Kecamatan Pahandut. Dari hasil wawancara dengan kepala KUA Kecamatan Pahandut terdapat dua faktor yang mempengaruhi pelaksanaan bimbingan pernikahan bagi calon pengantin:

a. Faktor pendukung pelaksanaan pembinaan pranikah

Menurut pembimbing yang selama ini memberikan bimbingan pranikah faktor pendukung yang menjadikan proses bimbingan pranikah berjalan efektif, berikut ini kutipan hasil wawancara peneliti.

"Ya kesediaan peserta calon

\begin{tabular}{|c|c|c|c|c|c|}
\hline No & Indikator & $\begin{array}{c}\text { Jumlah } \\
\text { Skor }\end{array}$ & Persentase & $\begin{array}{l}\text { Rata- } \\
\text { Rata }\end{array}$ & Kategori \\
\hline $\mathrm{I}$ & Tata Cara Akad & 51 & 91.07 & \multirow{10}{*}{83.04} & \multirow{10}{*}{ Tinggi } \\
\hline 2 & $\begin{array}{l}\text { Kesehatan } \\
\text { Reproduksi }\end{array}$ & 48 & 85.71 & & \\
\hline 3 & Sholat Wajib & 48 & $85.7 I$ & & \\
\hline 4 & Sholat Jama'ah & 45 & 80.36 & & \\
\hline 5 & $\begin{array}{l}\text { Membaca al- } \\
\text { Qur'an }\end{array}$ & 44 & 78.57 & & \\
\hline 6 & Banyak Berdoa & 51 & 91.07 & & \\
\hline $\mathrm{CCCCC7}$ & Banyak Berusaha & 52 & 92.86 & & \\
\hline 8 & Giat Bekerja & 50 & 89.29 & & \\
\hline 9 & Tawakal kpd Allah & 45 & 80.36 & & \\
\hline 10 & Bersyukur & 31 & 55.36 & & \\
\hline
\end{tabular}

memaafkan orang lain tidak mudah merasa sepi dan mudah mengontrol amarah sehingga terhindar dari depresi, kecemasan dan iri hati. Berdasarkan tabel di atas diperoleh data bahwa sebanyak $37,71 \%$ sangat setuju, $50.00 \%$ setuju dan $14,29 \%$ kurang setuju. Hal ini diperkuat dengan hasil wawancara dengan calon pengantin sebagai berikut:

Ya bersyukur sekali. Dari kami kenal kemudian pacaran dengan lika-liku akhirnya sebentar lagi kejenjang yang sangat dinanti-nantikan. Semoga nanti maut yang memisahkan

kami.Berdasarkan penjelasan di atas, dapat disimpulkan bahwa peningkatan pemahaman keagamaan calon pengantin adalah tinggi $(83,04 \%)$. Hal ini seperti digambarkan dalam tabel berikut:

pembimbing yang berkompenten dalam bidangnya masing-masing, misal Dinas kesehatan menyampaikan tentang kesehatan dan penyuluhan KB. Kalau dari KUA menyampaikan tentang keluarga sakinah, uu perkawinan".

Ada beberapa factor pendukung sehingga pelaksanaan pembinaah berjalan dengan baik, diantaranya adalah:

\section{I) Antusiasme peserta}

Menurut Joko Sudarso, antusias merupakan bentuk sikap ketertarikan atau sepenuhnya terlibat dengan suatu kegiatan karena menyadari pentingnya atau bernilainya kegiatan tersebut. Hal ini diperkuat dengan wawancara dengan calon pengantin

Saya sangat senang mengikuti pembinaan ini, karena kegiatan akan menjadi bekal kami berdua dalam mengarungi kehidupan berumah tangga.

$$
\text { Program bimbingan }
$$

pranikah cukup diminati oleh calon pasangan pengantin semua yang hadir dalam program ini menyimak dengan baik dan rasa ingin tahunya cukup, pertanyaan yang diajukan peserta tidak terlalu banyak, mungkin karena mereka masih amslu-malu bertanya 
mengenai persoalan pernikahan. Calon pasangan ynag tidak hadir pun ada dengan alasan tidak dapat izin dari tempat kerja.

2) Pembimbing yang cukup kompeten Salah satu faktor utama yang sangat berpengaruh dalam keberhasilan pembinaan adalah keberadaan Pembimbing. Mengingat keberadaan pembimbing dalam proses kegiatan pembinaan catin sangat berpengaruh, maka sudah semestinya kualitas pembimbing perlu diperhatikan. $\mathrm{Hal}$ ini diperkuat dengan hasil

adalah pembim-bing yang memiliki wawasan yang luas, khususnya tentang materi yang berhubungan dengan pelaksananaan bimbingan pranikah. Untuk materi UU Perkawinan dan keluarga sakinah pembimbing bisa dari pegawai KUA namun untuk materi kesehatan reproduksi pemateri berasal dari Puskesmas Kecamatan yang merupakan salah satu pengurus BP-4.

3) Metode penyampaian yang sangat sederhana

Metode adalah cara yang teratur dan terpikir baik-baik untuk mencapai maksud atau cara yang tersistem untuk memudahkan pelaksanaan suatu kegiatan guna mencapai tujuan yang ditentukan. Slameto mengartikan bahwa metode adalah jalan yang harus dilalui untuk mencapai tujuan. Metode yang disampaikan oleh pembimbing menggunakan metode ceramah (tatap muka), tanya jawab dan pendekatan berdasarkan pengalaman pembimbing atau orang lain yang dapat disesuaikan sebagai pegangan dalam tindakan masing-maisng individu. Dengan bahasa yang mudah dimengerti oleh peserta bimbingan pranikah membuat suasana bimbingan pranikah tenang dan nyaman. Hal ini diperkuat dengan hasil wawancara dengan calon pengantin, yaitu:

Kalau
menggunakan media agak
menarik untuk dilihat dan di

wawancara dengan calon pengantin yaitu:

Sebenarnya pembinaan di KUA untuk calon pengantin hampir mirip dengan belajar di sekolah, hanya kalau di sini lebih santai dan nonformal. Tapi dari sisi materi dan pemateri sama. Kalau pematerinya bagus maka mendengarkan penjelasannya juga enak dan mudah dipahami. Namun kalau pemateri kurang menyenangkan, maka kami juga malas dan mengantuk.

Pembimbing yang

berkompeten di bidangnya

dengar. Tidak bosenin, apalagi pembimbing memiliki selera humor sehingga menjadi akrab.

b. Faktor Penghambat pelaksanaan pembinaan pranikah

Setiap program pasti ada faktor pendukung dan faktor penghambat. Dari hasil wawancara peneliti dengan pegawai KUA yang menjadi sampel faktor penghambat terlaksananya bimbingan pranikah, berikut:

"Kalau hambatan itu pasti ada misal sehari petugas menargetkan pembinaan calon pengantin tetapi dalam satu hari jumlahnya tidak sesuai dengan yang ditargetkan. Dikarenakan peserta bimbingan pranikah masih ada yang berkerja dan masih ada yang diluar kota".

Dapat diuraikan bahwa faktor penghambat dalam pelaksanaan bimbingan pranikah di KUA Kecamatan Pahandut yaitu:

I) Sarana dan prasarana yang belum memadai

Sarana mempunyai arti penting dalam pembinaan calon pengantin. Ruangan misalnya sebagai tempat yang strategis bagi berlangsungnya kegiatan pembinaan. Ruangan yang representative akan meningkatkan animo peserta pembinaan calon pengantin menjadi meningkat, dan akan mengurangi dampak perceraian di kalangan masyarakat. Hal ini diperkuat dengan hasil wawancara dengan calon pengantin.

Kalau ruangannya luas dan nyaman seperti ada ac, bersih dan tidak desak-desakan maka mengikuti pembinaan menjadi 


nyaman. Tapi ralau
ruangannya sempit dan
berdesak-desakan mending
gak usah ikut saja.

2) Materi bimbingan pranikah yang kurang lengkap

umum tentang agama dan rumah tangga.

Menurutku ada beberapa materi yang seharusnya ada namun belum tersampaikan. Mungkin karena waktu yang terbatas atau memang belum terpikirkan oleh pihak KUA.

3) Kurang disiplinnya peserta

Disiplin merupakan suatu sikap/perilaku yang pasti diharapkan oleh setiap calon pengantin agar kegiatan pembinaan yang dilakukan baik dan dapat berjalan sesuai dengan yang diharapkan. Kedisiplinan menjadi alat yang ampuh dalam mendidik karakter. Banyak orang sukses karena menegakkan kedisiplinan. Banyak agenda yang telah ditetapkan tidak dapat berjalan karena kurang disiplin. Menurut pengamatan peneliti, banyak peserta pembinaan pranikah datang tidak tepat waktu, dan lebih mengutamakan datang pada saat pengecekan data. Hal ini diperkuat dengan hasil wawancara:

Bagaimana ya pak? Kami kan kerja juga sehingga harus pandai-pandai mengatur waktu akan pekerjaan tidak berantakan dan tidak kena semprot bos. Sebenarnya pembinaan seperti ini sangat penting untuk rumah tangga kami ke depan.

4) Keterbatasan waktu

Pemberian bimbingan
pranikah diisi oleh dua orang
pembimbing. Setiap pembimbing
diberikan waktu hanya satu jam, ini
menyebabkan terbatasnya metari
yang diuraikan dan kurangnya kesempatan bagi peserta yang megikuti bimbingan pranikah untuk berdialog lebih berhak.

Materinya terlalu banyak sedangkan waktunya sedikit sehingga malah tertalu padat. Materi yang seharusnya mudah dipahami menjadi ruwet.

5) Tempat tinggal calon pengantin
Sebenarnya bahan atau kurikulum tentang pembinaan calon pengantin sudah diatur oleh perantuan pemerintah. Namun materi yang tercantum masih seputar pengetahuan yang bersifat Ada di antara para calon pengantin yang akan mengikuti pembinaan pranikah jauh dari kawasan Kantor Urusan Agama Kecamatan Pahandut. Keterbatasan dari kawasan calon pengantin yang kadangkala mereka sulit memahami materi bimbingan dan ruangan pembinaan pranikah yang kurang luas untuk pelaksanaan bimbingan pranikah.

Kebetulan jarak rumah kami lumayan jauh sehinga agak bingung berangkatnya. Sarana

\section{Kesimpulan} transportasi juga terbatas.

Dari hasil kajian yang telah dilakukan oleh peneliti, maka penelitian ini menyimpulkan sebagai berikut:

I. Pola pembinaan yang dilakukan KUA Kecamatan Pahandut meliputi model pembinaan, pembimbing pembinaan, materi pembinaan, metode pembinaan dan waktu pembinaan. Secara kesimpulan tingkat pola pembinaan termasuk kategori baik (79,29\%).

2. Tingkat pemahaman keagamaan meliputi pemahaman akad nikah, pemahaman kesehatan reproduksi, pemahaman ibadah dan pemahaman psikologi keluarga. Secara kesimpulan tingkat pemahaman keagamaan termasuk kategori 'Tinggi' (83,04\%).

3. Factor pendukung pembinaan meliputi antusiasme peserta, pembimbing yang kompeten dan metode penyampaian yang sangat sederhana. Sedangkan factor penghambat meliputi sarana dan prasana yang belum memadai, materi bimbingan yang kurang lengkap dan waktu bimbingan yang sangat singkat.

\section{Daftar Pustaka}

Abdul Rahman Ghozali, Figh Munakahat, Jakarta: Kencana, 2013

Abdurrahman, Kompilasi Hukum Islam di Indonesia, Jakarta: Akademika Pressindo, 2015.

Achmad Kuzari, Nikah sebagai Perikatan, Jakarta: Raja Grafindo Persada, 2015.

Amir Syarifuddin, Hukum Perkawinan Islam di Indonesia, Jakarta: Prenada Media, Cet. 2, t.th. 
Baihaqi, Ahmad Rafi, Membangun Surga Rumah Tangga, Surabaya: Gita Mediah Press, 2016.

David Wattimena dan Piatno $\mathrm{H}$. Martokoesoemo, Spiritual Happiness, Bandung: Mizania, 20II.

Hisyam Zaini, dkk, Desain Pembelajaran di Perguruan Tinggi, Yogyakarta: CTSD IAIN Sunan Kalijaga, 2012.

Imam Taqiyuddin Abu Bakar bin Muhammad alHusaini, Kifayah al-Akhyar fi Halli Ghayati al-lkhtishar, Jakarta: Dar al-Kutub alIslamiyah, cet. 7, 2017.

Joko Sudarto, Sistem Pendidikan Nasional, Jakarta: Rineka Cipta, 2013.

ta, Jakarta: Pustaka al-Kautsar, 2018.
Lexy J. Moleong, Metodologi Penelitian Kualitatif, Bandung: Remaja Rosda karya, 2014.

Moh. Idris Ramulyo, Hukum Perkawinan Islam, Jakarta: Bumi Aksara, 2015.

Nur Ahid, Pendidikan Keluarga dalam Perspektif Islam Yogyakarta: Pustaka Pelajar, 2016.

Rahman, Fazlur, Islam, penerjemah Ahsin Mohammad, (Bandung: Pustaka, 20I0).

Slameto, Proses Belajar Mengajar dalam

Sistem SKS, Jakarta: Bumi Aksara, 2018.

Sugiyono, Memahami Penelitian Kualitatif, Bandung: Alfa Beta, 20I5, hlm. 92.

'Uwaidah, Syaikh Kamil Muhammad, Fiqih Wani 